International Research Journal of Management, IT \& Social Sciences
Available online at https://sloap.org/journals/index.php/irjmis/
Vol. 8 No. 1, January 2021, pages: 19-24
ISSN: 2395-7492
https://doi.org/10.21744/irjmis.v8n1.1067

\title{
Legal Protection Against the Existence of "Wetu Telu" Traditional Society Against Law Number 11/2020 Concerning Work Creation (Omnibus Law)
}

Article history:

Submitted: 18 October 2020

Revised: 27 November 2020

Accepted: 09 December 2020

\section{Keywords:}

adat recht; constitution;

Islamic nuances; omnibus law;

wetu telu;

\begin{abstract}
The Wetu Telu indigenous people in Bayan, North Lombok have the traditions of their ancestors that have Islamic nuances and their existence is recognized until now. The existence of indigenous peoples has been recognized and respected by the 1945 Constitution. However, the existence of new laws and regulations on indigenous peoples has again encountered problems that threaten their existence. The Omnibus Law which was recently passed is considered to provide a legal loophole that could displace the existence of indigenous peoples. The purpose of this research is to find out the legal problems of the threat to the existence of the Wetu Telu indigenous people and to know the concept of the Work Creation Act (Omnibus Law) in Bayan Village, North Lombok Regency, West Nusa Tenggara. This research uses juridical empirical or socio-legal research, which is a type of sociological legal research or field research that examines applicable legal provisions. The results of this study show that the normative issue of the Omnibus Law can lead to norm conflicts with other laws regarding the recognition of indigenous peoples in Indonesia.
\end{abstract}

International research journal of management, IT and social sciences (C) 2021. This is an open access article under the CC BY-NC-ND license (https://creativecommons.org/licenses/by-nc-nd/4.0/).

\section{Corresponding author:}

Irham Rahman,

Universitas Kadiri, Kediri, East Java, Indonesia.

Email address: irhamrahman@unik-kediri.ac.id

a Universitas Kadiri, Kediri, East Java, Indonesia

${ }^{\mathrm{b}}$ Universitas Kadiri, Kediri, East Java, Indonesia 


\section{Introduction}

The existence of customary law and the rights of indigenous peoples in Indonesia has been recognized and respected by the State, as clearly contained in the constitution of Article 18B paragraph (2) of the 1945 Constitution of the Republic of Indonesia (UUD NRI 1945) states that the State recognizes and respect indigenous peoples and their traditional rights as long as they are alive and following the development of society and the principles of the Unitary State of the Republic of Indonesia (NKRI), supplemented by Article 28 I paragraph (3) that the cultural identity and rights of traditional communities are respected in line with developments times and civilizations. With these provisions, it is clear that there is a form of regulation on the recognition of the existence of indigenous peoples with two conditions that must be fulfilled, namely following community development and not against the principles of the Republic of Indonesia. As part of the social reality in Indonesia, the meaning of the existence of indigenous groups cannot be ignored, there is even a tendency that their existence must be maintained and fought for as cultural rights as part of Human Rights which has been regulated in the constitution and a collective agreement in the association of the nations of the world to be obeyed (Haug \& Larsen, 1966; Ringwood, 1991).

The Wetu Telu indigenous people come from the Sasak people who are located in Bayan, North Lombok. The indigenous people of the island of Lombok are the Sasak tribe and according to sociological scientists such as Van Eerde and Professor Bousquet in the Sasak tribe community, there are three religious groups, namely, Sasak Boda, Wetu Telu, and Waktu Lima. Sasak Boda is the native religion of the people of Lombok which adheres to a belief system of animism and pantheism (worship and worship of ancestral spirits and local gods). Wetu Telu is a teaching that has Islamic nuances but adheres to the customs of their ancestors (Suwitha, 2016). Meanwhile, Waktu Lima is an Islamic religion, in general, that is obedient and perfect in carrying out religious teachings, such as praying, paying zakat, fasting, performing the pilgrimage, and so on. The customs of the Wetu Telu people have been passed down from generation to generation to maintain and maintain the customs of their ancestors, which normatively the Wetu Telu indigenous people receive recognition as indigenous people.

On October 5, 2020, through the plenary meeting of the House of Representatives of the Republic of Indonesia (DPR RI), it has signed Law Number 11 of 2020 concerning Job Creation (Job Cipta Law) or commonly called the Omnibus Law. Then-President Jokowi signed the manuscript on Monday, November 2, 2020, and it was officially promulgated in the state gazette on the same date. The law has been criticized for limiting basic labor rights and stripping environmental protection, including by threatening indigenous peoples' access to land and the environment. The passing of this law prioritizes investors or businessmen for ease of investing in Indonesia. The existence of indigenous peoples will be further marginalized by the government's plan to issue replacements for overlapping laws. Omnibus law as a form of plan to replace overlapping laws makes indigenous peoples increasingly threatened and marginalized from their existence in the archipelago (An'Amta et al., 2020). Territorial boundaries that are owned and recognized based on consensus internally in the Dayak customary community and externally from the local government will be swept away by the authority of the central government.

\section{Materials and Methods}

This research uses juridical empirical or socio-legal research, which is a type of sociological legal research or field research that examines the provisions of applicable laws and what happens in society. This means that research is carried out on the actual situation or real conditions that occur in society to know and find the facts needed, after the data is collected then the problem identification stage can finally solve the problem (Sunggono, 2003). This research was conducted in Bayan Village, North Lombok Regency, West Nusa Tenggara by identifying the existence of customary law and conducting a study of Law Number 11 of 2020 concerning Job Creation (UU Cipta Kerja) or commonly called the Omnibus Law.

\section{Results and Discussions}

\subsection{The Wetu Telu Indigenous People}

Customary law communities have customary values that must be preserved as the culture and identity of the Indonesian people for the development of a dignified and prosperous society as mandated by the Constitution. The existence of 
indigenous peoples in regions in Indonesia must obtain recognition and protection of their rights through legal certainty, the recognition of indigenous peoples from the law in a normative manner, and the implementation or enforcement of their rights in the field empirically. Such as the Wetu Telu Indigenous Community in Bayan, North Lombok, who still adhere to the customs of their ancestors and maintain the customary buildings that they believe exist as indigenous peoples to be included in the concept of customary law. To find out the existence of customary law, it can be measured from the following characteristics (Subari et al., 2010); First, it is not written, and even if there is something that is written it is not made by the legislative body. Second, it has four characteristics of customary law, namely:

a) Religiomagic, which means that customary law contains an element of belief in supernatural powers and is not based on logic.

b) Communal, meaning that customary law regulates common interests and the rules are generally accepted.

c) Cash, shows that transactions in customary law have symbolic actions.

d) Concrete, means that customary law that shows the validity of a legal relationship that occurs in real-time or the act is given the form of an object.

The Wetu Telu custom in Bayan Village, Bayan Subdistrict, North Lombok Regency (KLU) is the Wetu Telu Indigenous People who are Sasak people who have Islamic nuances, but they still adhere to the customs of their ancestors. Wetu Telu also has several rituals that are often performed. First, in building a house the Wetu Telu community has its rituals in its construction, both modern and traditional houses. In this case, it is not only a ritual but also the calculation of Wete Telu in each process. Second, when one of the Wetu Telu people marries another person outside the Wetu Telu community, that person must carry out a purification process. This process is carried out to eliminate the negative aura of the person and to adapt the person's aura to the Wetu Telu community. The three Wetu Telu communities have their requirements and rituals for migrants who then want to become part of their community (Suwena et al., 2010). In addition to these values, the Wetu Telu people also have several beliefs, first, indigenous people or immigrant communities are not allowed to enter the forest and customary tombs using sewn clothes. Second, the Wetu Telu people believe that the disaster that occurs is related to deviant behavior by the community. One example is when there is a long drought, the traditional leaders will perform rituals to make it rain. However, besides that, customary leaders will find out what deviant acts have been committed. Second, the Wetu Telu community has a special month, where people are prohibited from holding activities except for birth and death (Sahir, 2020).

The customs in the Wetu Telu community are protected in three laws, namely, customary law (tradition), religious law (religion), and government law (civil law or administrative law) (Aniq, 2011). Meanwhile, to ensure that the three laws are carried out properly, in the Wetu Telu community five traditional leaders have different roles and functions, while the five traditional leaders include: First Mangku, namely the person in charge of managing the development, the economy, and so on. The two Mekels, namely people who sit in government seats. The three Penghulu, who served in the religious sector (Rachmadani, 2011). The fourth is Raden, namely, people who function in matters of customary rituals and the last is Turun, a person who is in charge of maintaining and supervising security (Sahir, 2020). Of the five traditional leaders are descendants, so the only ones who can become the five traditional leaders are descendants, and in Wetu Telu society adheres to a patriarchal system, where the one who carries offspring is male. However, along the way, the roles of the five traditional leaders began to be limited, so that some of the Wetu Telu cultures began to change.

The Wetu Telu indigenous people as the object of the tourism industry and as a tourist destination force the community, either directly or indirectly, to develop and experience change. According to the author, three factors influence the Wetu Telu indigenous people which can be a challenge to maintain their customary law, these factors include:

1) Tourism Development

The location of the Wetu Telu indigenous people, namely Bayan District, is a tourist destination because this place is one of the climbing routes to Mount Rinjani which is well known abroad. This location is very strategic and can attract tourists to the Wetu Telu indigenous people so that Bayan has the potential to develop the tourism industry. The development of the tourism industry can have an impact on the Wetu Telu Indigenous People. For example, the Government's policy is to oblige tourism industry players in Bayan to use the services of local people to become tour guides and porters for tourists who want to climb Rinjani. Therefore, the government provides training in English and procedures for serving tourists to support this policy (GIZ, 2014). Efta (2020), an informant said that tourism development in Bayan requires not only the younger generation but also the older generation to be able to

Rahman, I., \& Bramantyo, R. Y. (2020). Legal protection against the existence of "Wetu Telu" traditional society against law number 11/2020 concerning work creation (omnibus law). International Research Journal of Management, IT and Social Sciences, 8(1), 19-24. https://doi.org/10.21744/irjmis.v8n1.1067 
speak foreign languages. This demand for the development of the tourism industry to change the lifestyle of the Wetu Telu Indigenous Peoples, especially in the field of National Identity as indigenous peoples.

2) Modern and Indigenous Wetu Telu Society

Tourism is one of the strategies developed by the Indonesian government to accelerate development in disadvantaged areas. This development strategy places local people in a difficult position. On the one hand, local people are required to mingle with tourists and on the other hand, local people are required to preserve their culture. In the Wetu Telu community, they are not able to play these two roles simultaneously which in turn changes their customs. For example, in terms of clothing and traditional house buildings, it is starting to be difficult to maintain. The changes that occurred in the Wetu Telu community as a result of the development of tourism have transformed the Wetu Telu community into a modern society. Huntington explained that when a traditional society turned into a modern society, there was a change in the pattern of life of the traditional society, which involved behavior and ways of thinking. These changes specifically include industrialization, urbanization, social mobilization, diversity, secularization, media expansion, reduced illiteracy and education, and people becoming politically aware. In simple terms, traditional societies begin to change like the dominant society or society in general (Huntington, 1971).

3) Introduction to Technology

The tourism industry to develop the tourism industry by facilitating information and technology. To attract industrial tourists is required to promote through the world of the internet, therefore tourism development introduces technology to the Wetu Telu Indigenous Community in Bayan. When Bayan tourism is growing rapidly, many people from outside Bayan come and earn income in Bayan, they come with a higher educational background than the Wetu Telu community. So that their mobility runs faster than the Wetu Telu community. This then makes migrants in the Bayan tourism industry one step ahead of the Wetu Telu community.

\subsection{Legal Consequences of Law Number 11 of 2020 concerning Job Creation for Indigenous People}

The passing of Law Number 11 of 2020 concerning Job Creation or another term called the Omnibus Law is a newly legal product for the legal system in Indonesia which adheres to the civil law system. The implementation of the Omnibus Law is used in countries that adhere to the common law system such as the United States, Ireland, and Canada (Prabowo et al., 2020). Indonesia, which adheres to the civil law system, produces and has a target of making new laws every year. The rule of law in Indonesia should reduce dependence on the formation of laws by further enhancing the position, role, and quality of the judiciary in solving various legal problems in practice (Asshiddiqie, 2019). Many laws and regulations have the risk that there is the possibility of legal or regulatory conflicts that conflict with each other and the complexity of the bureaucracy in the implementing regulations. Therefore, President Jokowi made a new song, namely the Omnibus Law. The term Omnibus Law starts with the word Omnibus. The word Omnibus comes from Latin and means for everything. In Black's Law Dictionary, 10th is mentioned omnibus: relating to or dealing with numerous object or item at once; including many things or having various purposes, which means relating to or dealing with various objects or items at once; include many things or have multiple purposes. When coupled with the word Law, it can be defined as law for all (Hadikusuma, 2003). The Omnibus Law is a step to simplify regulations in Indonesia and is expected to cut bureaucracy and can provide convenience for businessmen for investors in Indonesia (Waluyo, 2002). But the Omnibus Law is not what some people expect and causes controversy, especially for laborers or workers and indigenous peoples.

Every law made must refer to the 1945 Constitution of the Republic of Indonesia as the Constitution in Indonesia. The Job Creation Law has several conflicts with the 1945 Constitution against Indigenous Peoples. This is evidenced by the elimination of provisions in the Law on Environmental Protection and Management which exclude agricultural activities by burning as an expression of local culture and wisdom of Indigenous Peoples. The removal of the exempt article from the Law on Protection and Management of the Environment clearly shows an anti-indigenous attitude towards indigenous peoples who practice their local wisdom and culture in managing customary territories. The elimination of these exceptions is a denial and violation of the 1945 Constitution, especially Article 28I paragraph (3) of the 1945 Constitution of the Republic of Indonesia. Also, in Article 69, the Job Creation Law removes the exception for Indigenous Peoples to farm by burning as previously recognized in the Law. Protection and management of the environment. The rights of indigenous peoples are excluded from the interests of investors which are the main objective of this legislation. The Job Creation Law makes it easy for investors to invest in Indonesia, as for some of these provisions, among others:

a) Right to Cultivate 90 years. This means that the confiscated customary territory only can return to the Indigenous Peoples after 90 years. It took almost 2 generations. 
b) The Job Creation Law only provides administrative sanctions to businesses conducting business without a business license (Article 82A). Businesses that violate business licenses and government approvals are only subject to administrative sanctions. In short, there are no criminal sanctions against businesses that conduct business without a license or violate their business license.

c) Business actors who use customary areas without the consent of the Indigenous Peoples will only be given administrative sanctions (no criminal sanctions). This is regulated in Article 22 of the Agricultural Cultivation System cluster.

The existence of the Job Creation Law can threaten the existing Indigenous Peoples Protection Policy. So far, there have been many Regional Regulations in the Regency / City, Province that has recognized existing Indigenous Peoples. The existence of these various Regional Regulations is threatened with being repealed by the government through the authority granted by the Job Creation Law if the existence of these Regional Regulations hinders the authority of the central government in converting forest areas into business areas and on the grounds of preventing investment. Also, customary communities who have lived for years, such as the Wetu Telu indigenous people, who own customary land and forests, are at risk of having no place to live (Albu, 2016).

\section{Conclusion}

The Wetu Telu Indigenous People are indigenous peoples whose rights in positive law in Indonesia have been recognized and protected to maintain their customary traditions and traditional structures that have been passed down from generation to generation. The government's strategy to issue an Omnibus law to simplify regulations and attract investors is a good policy for economic growth. However, this step had an impact on the threat of waning the existence of the Wetu Telu indigenous people. The existence of the Wetu Telu Indigenous Peoples places directly on government policies to obtain legal protection for the impact on the sustainability of the Wetu Telu Indigenous Peoples' customary lands and forests, which they maintain to date. To preserve the culture and place for indigenous peoples, normative legal protection must be carried out without reducing or weakening the laws and regulations related to the recognition of the existence of indigenous peoples (Chen et al., 2009; Montefalcone et al., 2009; Bader, 2007).

\section{Conflict of interest statement}

The authors declared that they have no competing interests.

\section{Statement of authorship}

The authors have a responsibility for the conception and design of the study. The authors have approved the final article.

\section{Acknowledgments}

We are grateful to two anonymous reviewers for their valuable comments on the earlier version of this paper.

\footnotetext{
Rahman, I., \& Bramantyo, R. Y. (2020). Legal protection against the existence of "Wetu Telu" traditional society against law number 11/2020 concerning work creation (omnibus law). International Research Journal of Management, IT and Social Sciences, 8(1), 19-24. https://doi.org/10.21744/irjmis.v8n1.1067
} 


\section{References}

Albu, C. E. (2016). Tourism and terrorism: A worldwide perspective. CES Working Papers, 8(1), 1.

An'Amta, DAA, Hamid, I., \& Fahrizan, ML (2020). Balai Kiyu Indigenous People: Facing Threats of Existence in Their Own Land. RESIPROCAL: Journal of Actual Progressive Sociology Research , 2 (1), 39-53.

ANIQ, A. F. (2011). Lombok Islam In The Eyes Of Anthropologists. Al Qalam, 28(2), 197-216.

Asshiddiqie, J. (2019). Omnibus Law (Omnibus Law), Simplification of Legislation, and Administrative Codification [Omnibus Law, Legislation Simplification and Administrative Codification].

Bader, M. A. (2007). Extending legal protection strategies to the service innovations area: Review and analysis. World Patent Information, 29(2), 122-135. https://doi.org/10.1016/j.wpi.2006.10.013

Chen, K. C., Chen, Z., \& Wei, K. J. (2009). Legal protection of investors, corporate governance, and the cost of equity capital. Journal of corporate finance, 15(3), 273-289. https://doi.org/10.1016/j.jcorpfin.2009.01.001

Efta, R., 2020. Culture and Change in Wetu Telu Society

Hadikusuma, H. (2003). Introduction to Indonesian customary law . Mandar Maju |

Haug, A., \& Larsen, B. (1966). A study on the constitution of alginic acid by partial acid hydrolysis. In Proceedings of the Fifth International Seaweed Symposium, Halifax, August 25-28, 1965 (pp. 271-277). Pergamon. https://doi.org/10.1016/B978-0-08-011841-3.50043-4

Huntington, S. P. (1971). The change to change: Modernization, development, and politics. Comparative politics, 3(3), 283-322.

Montefalcone, M., Albertelli, G., Morri, C., Parravicini, V., \& Bianchi, C. N. (2009). Legal protection is not enough: Posidonia oceanica meadows in marine protected areas are not healthier than those in unprotected areas of the northwest Mediterranean Sea. Marine Pollution Bulletin, 58(4), 515-519. https://doi.org/10.1016/j.marpolbul.2008.12.001

Prabowo, A. S., Triputra, A. N., \& Junaidi, Y. (2020). Politik Hukum Omnibus Law di Indonesia. Pamator Journal, 13(1), 1-6.

Rachmadani, A. (2011). Local Wisdom Wetu Telu Islamic Marriage Tradition as the Bond of Harmony in the Community of Bayan, Semarang: Researcher at the Research and Development Center for the Research and Development Center for Religion Semarang.

Ringwood, A. E. (1991). Phase transformations and their bearing on the constitution and dynamics of the mantle. Geochimica et Cosmochimica Acta, 55(8), 2083-2110. https://doi.org/10.1016/0016-7037(91)90090-R

Sahir. (2020). Wetu Telu Community Culture.

Subari, AS, Albariansyah, H., \& Flambonita, S. (2010). The Principles of Customary Law. Publisher Sriwijaya University. Palembang.

Sunggono, B. (2003). Legal research methodology. Jakarta: PT. RajaGrafindo Persada.

Suwena, IK, Widyatmaja, IGN, \& Atmaja, MJ (2010). Basic knowledge of tourism science. Udayana University Press.

Suwitha, I. P. G. (2016). Islamic society diaspora of Bugis descent in Bali. International research journal of management, IT and social sciences, 3(5), 48-58.

Waluyo, B. (2002). Legal Research in Practice. Sinar Grafika, Jakarta. 